\title{
UNITED
}

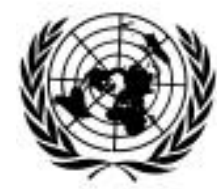

\section{United Nations Conference on Trade and Development}

Distr.

GENERAL

TD/B/COM.2/ISAR/30*

26 September 2005

Original: ENGLISH

TRADE AND DEVELOPMENT BOARD

Commission on Investment, Technology and Related Financial Issues

Intergovernmental Working Group of Experts on

International Standards of Accounting and Reporting

Twenty-second session

Geneva, 21-23 November 2005

Item 5 of the provisional agenda

\section{GUIDANCE ON GOOD PRACTICES IN CORPORATE GOVERNANCE DISCLOSURE**}

Executive summary
At UNCTAD's tenth quadrennial conference (Bangkok, February 2000), member States called on
the Intergovernmental Working Group of Experts on International Standards of Accounting and
Reporting (ISAR) to promote increased transparency and improved corporate governance. Since that
time, a number of corporate failures have highlighted the need for improvements in corporate
governance in developed and developing countries alike. In 2002, UNCTAD produced a report on
transparency and disclosure requirements for corporate governance for the nineteenth session of ISAR
(TD/B/COM.2/ISAR/15). At its twenty-first session, ISAR requested UNCTAD to provide an
updated version of that report; it was agreed that an updated version could be a useful tool for
promoting good practices and that further efforts should be made to disseminate it.
This report represents a revised and updated version of the 2002 report. It was prepared by the
UNCTAD secretariat on the basis of discussions with an ad hoc Consultative Group which was
formed during the intersessional period. These discussions focused on developments in corporate
governance disclosure since 2002. As a result of these discussions, some new disclosure items were
identified, and a number of revisions were made to the explanatory text in order to bring the 2002
report up to date with current practices. In particular, new disclosures include: changes in control and
transactions involving significant assets, the existence of an ethics policy and support structure, the
selection process for the external auditor, the role of the internal audit function, and the process by
which shareholders can submit agenda items.
This guidance covers financial and non-financial corporate governance disclosures, as well as
disclosure issues regarding general meetings, timing and means of disclosure, and compliance with
best practice. It also contains a list of useful references on regional and international corporate
governance disclosure guidance.

\footnotetext{
* Re-issued for technical reasons.

** This document was submitted on the above-mentioned date as a result of processing delays.
} 
Page 2

\section{CONTENTS}

Page

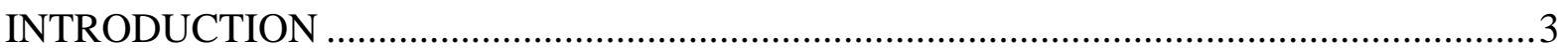

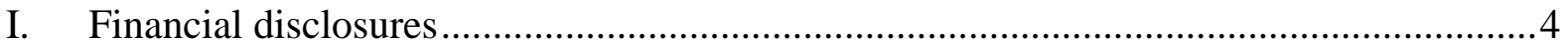

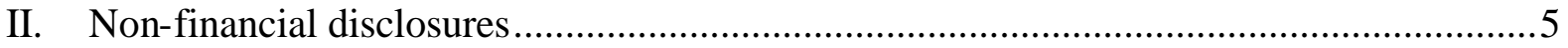

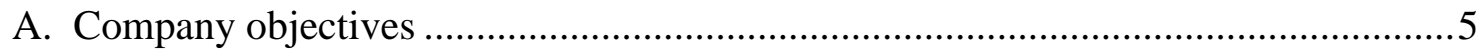

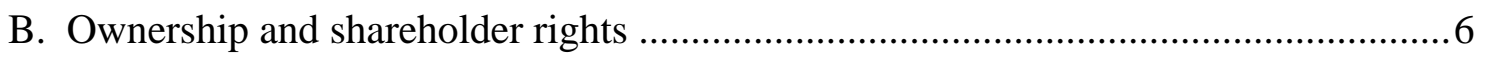

C. Changes in control and transactions involving significant assets ............................ 7

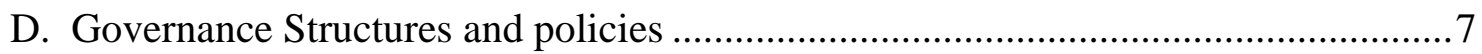

E. Members of the board and key executives ............................................................ 10

F. Material issues regarding stakeholders, environmental and social stewardship .......12

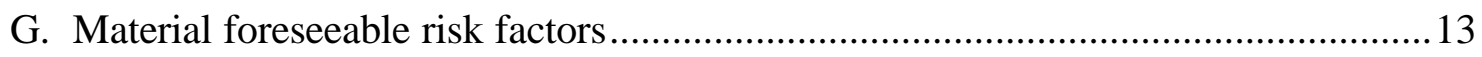

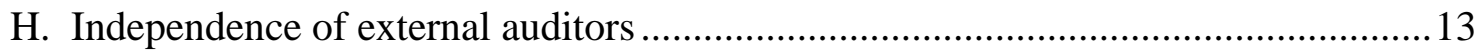

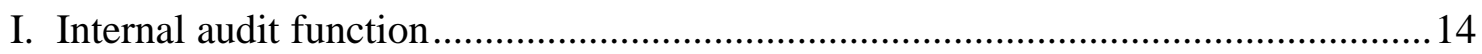

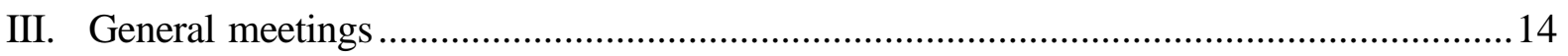

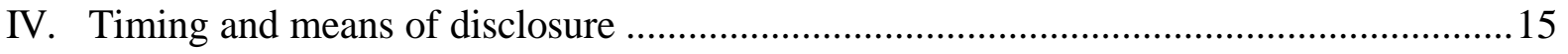

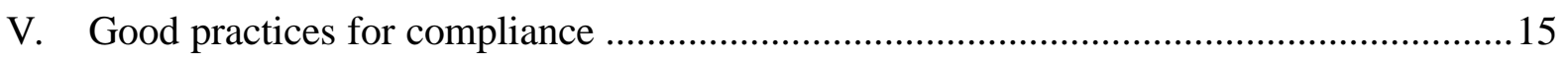

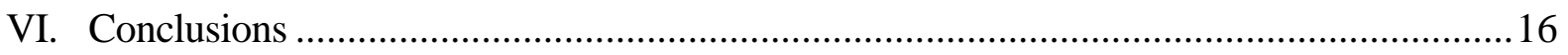

\section{Annexes}

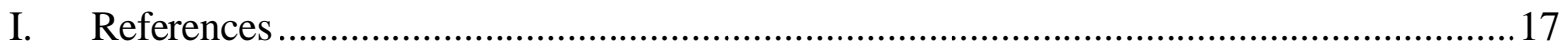

II. Members of the ad hoc Consultative Group …...............................................................2 23 


\section{INTRODUCTION}

1. At its tenth quadrennial conference, which was held in Bangkok in February 2000, member States requested UNCTAD to promote increased transparency and improved corporate governance. In response to the above request, the seventeenth session of the Intergovernmental Working Group of Experts on International Standards of Accounting and Reporting (ISAR) decided to review existing corporate governance practices, codes and principles. Accordingly, a review was conducted and was presented at the eighteenth session of ISAR.

2. In concluding the eighteenth session and adopting the provisional agenda for the nineteenth session, the Group of Experts proposed to work on issues related to corporate governance. Discussions focused on how ISAR could contribute to the improvement of corporate governance practices in member States and on how it could assist developing countries and economies in transition in identifying and implementing best corporate governance practices to achieve better transparency and accountability.

3. The work for the nineteenth session culminated in the 2002 report "Transparency and disclosure requirements for corporate governance" (referred to as ISAR/15). The objective of the report was to help developing countries and countries with economies in transition apply good practices of corporate governance disclosure.

4. At the twenty-first session of ISAR in 2004, the Group of Experts proposed reviewing the ISAR/15 report with a view to considering further developments in the area of disclosures and updating it as needed. Accordingly, an ad hoc consultative group was formed, consisting of experts from a range of countries and organizations and which met in Geneva on 18 May 2005 (see annex II).

5. The objective of the ad hoc consultations was to review the recommendations on corporate governance disclosures that are outlined in the 2002 ISAR/15 report in light of developments since 2002 and to update the original report as needed. This document draws upon recommendations for disclosure relevant to corporate governance contained in such widely recognized documents as the revised OECD Principles of Corporate Governance (OECD Principles), the International Corporate Governance Network (ICGN) Corporate Governance Principles, past ISAR conclusions on this matter, the Commonwealth Association for Corporate Governance Guidelines (CACG Guidelines), the pronouncements of the European Association of Securities Dealers (EASD), the EU Transparency Directive, the King II Report on Corporate Governance for South Africa (King II), the Report of the Cadbury Committee on the Financial Aspects of Corporate Governance (Cadbury Report), the Combined Code of the UK, the United States Sarbanes-Oxley Act, and many others (see annex I). References to codes in this report are provided by way of example only, and for every individual code highlighted, there may exist other codes that address the same issue in a similar way.

6. Reference is made to the recommendations contained in the foregoing documents, since one objective of this guidance is to illustrate the convergence of opinion on the content of corporate governance disclosures. Another objective of this guidance is to encourage countries and/or companies to implement best international practices in a way tailored to their particular legal requirements and local traditions by giving various examples of existing best practices.

7. During the ad hoc consultations, it was re-emphasized that ISAR's guidance on corporate governance disclosures would be a voluntary technical aid for, among others, regulators and companies in developing countries and transition economies. What and how organizations disclose will depend considerably on local laws and customs. In addition, particular industries may have some industry-specific disclosure requirements. In order to facilitate the general usefulness of this document, the focus is placed on widely applicable disclosure issues that should be relevant to most enterprises. The purpose of the work is to address the major concerns of investors and creditors, and to provide some reassurance, through disclosures on corporate governance. This work would be relevant to enterprises eager to attract investment regardless of their legal form or size. This guidance 


\section{Page 4}

would also be useful for promoting awareness in countries and companies that are not adhering sufficiently to international good practices and are consequently failing to satisfy investors' expectations regarding corporate governance disclosures.

8. The report revisits the content of major corporate governance codes and regulations since 2002, with a focus on: financial disclosures, a range of non-financial disclosures, disclosures in relation to general meetings, the timing and means of disclosures and the disclosure of the degree of compliance with local or other codes of corporate governance. The following sections present the main conclusions on these issues.

\section{FINANCIAL DISCLOSURES}

9. The ad hoc consultative group recognized as fundamentally important that enterprises should disclose their financial and operating results.

10. One of the major responsibilities of the board of directors is to ensure that shareholders and other stakeholders are provided with high-quality disclosures on the financial and operating results of the entity that the board of directors had been entrusted to govern. Almost all corporate governance codes around the world, including the OECD and the ICGN Principles, the CACG Guidelines, the Cadbury Report, and the King II, specifically require the board of directors to provide shareholders and other stakeholders with information on the financial and operating results of a company to enable them to properly understand the nature of its business, its current state of affairs and how it is being developed for the future.

11. The quality of financial disclosure depends significantly on the robustness of the financial reporting standards on the basis of which the financial information is prepared and reported. In most circumstances, the financial reporting standards required for corporate reporting are contained in the generally accepted accounting principles recognized in the country where the entity is domiciled. Over the last few decades, there has been increasing convergence towards a set of non-jurisdictionspecific, widely recognized financial reporting standards. The ad hoc consultative group agreed that International Financial Reporting Standards (IFRSs) issued by the International Accounting Standards Board provide a widely recognized benchmark in this respect.

12. Furthermore, the ad hoc consultative group was of the view that the board of directors could enrich the usefulness of the disclosures on the financial and operating results of a company by providing further explanation, for example in the Management's Discussion and Analysis section of the annual report, on critical accounting estimates ${ }^{1}$ of the company in addition to the disclosure required by the applicable financial reporting standards.

13. The board could clearly identify inherent risks and estimates used in the preparation and reporting of the financial and operational results of the company in order to give investors a better understanding of the risks they are taking in relying on the judgement of management. For example, in some cases, financial reporting measurement requirements call for the valuation of certain assets on a fair value basis. However, while for certain assets deep markets might exist and fair value could be obtained with reasonable objectivity, that might not be the case for others. Situations of the latter kind may invite management to exercise great latitude and influence the direction of earnings in its favour by resorting to less objective estimates based on modelling hypothetical markets. In addition to the disclosure required by the applicable financial reporting standards, the board of directors may provide

\footnotetext{
${ }^{1}$ An example of a definition of critical accounting can be found in the United States Securities and Exchange Commission Release number 33-8098, according to which an accounting estimate would be considered critical when it requires management to make significant judgement in making assumptions about matters that were highly uncertain at the time the estimate was made; and when alternative estimates that management could have reasonably used, or changes in the accounting estimate that are likely to occur from period to period have material impact on the financial and operating results of the company.
} 
further comfort to shareholders and other stakeholders by disclosing that the board or its audit committee has reviewed fair value computations, if any, and that the computations were conducted in an objective manner.

\section{The board's responsibilities regarding financial communications should be disclosed.}

15. A description of the board's duties in overseeing the process of producing the financial statements should be provided. This is useful for supporting the notion that the board is responsible for creating an overall context of transparency. It is generally accepted that the board has responsibility for reporting on the financial and operating results of the corporation. Almost all corporate governance codes describe the basic responsibility of the board for reviewing financial statements, approving them, and then submitting them to shareholders. When the duties of the board in this area are clearly disclosed, shareholders and other stakeholders could find it useful in providing an additional level of comfort with regard to the fact that the financial statements accurately represent the situation of the company.

16. The quality of financial disclosure could be undermined when consolidation requirements on financial reporting are not followed appropriately. In this respect, the board of directors could provide additional comfort to users of its financial reports. For example, the board of directors could state that it had ascertained that all subsidiaries and affiliated entities, including special purpose ones, which are subject to consolidation as per the financial reporting standards applicable to the entity, have been properly consolidated and presented.

17. The ad hoc consultative group was of the view that enterprises should fully disclose significant transactions with related parties.

18. Many shareholders and stakeholders would be interested in information that would help them determine that management is running the enterprise with the best interest of all shareholders and stakeholders in mind and not to unduly benefit any related-parties (see also section II.E.6 below on conflict of interest). Most national financial reporting standards, and IFRS, require extensive disclosure on this matter. However, in circumstances where the financial reporting requirements are less stringent, as a minimum the board of directors should provide the following disclosures that are generally considered best practice: significant related-party transactions and any related-party relationships where control exists; disclosure of the nature, type and elements of the related-party transactions; and related-party relationships where control exists (irrespective of whether there have been transactions with parties under common control). The decision-making process for approving related-party transactions should also be disclosed. Members of the board and managers should disclose any material interests in transactions or other matters affecting the company.

\section{NON-FINANCIAL DISCLOSURES}

\section{A. Company Objectives}

19. The ad hoc consultative group agreed that the objectives of the enterprise should be disclosed. There are two general categories of company objectives: the first is commercial objectives, such as increasing productivity or identifying a sector focus; the second is much more fundamental and relates to governance objectives: it seeks to answer the basic question, "why does the company exist?" This section refers to these governance objectives. The objectives of enterprises may vary according to the values of society. In many but by no means all countries, the primary corporate objective is to maximize the long-term return to shareholders (shareholder value). This objective appears in many codes throughout the world.

20. However, despite an increasing awareness throughout the world that shareholder requirements must be met in order to attract and retain long-term, low-cost capital, the emphasis on shareholder 


\section{Page 6}

value maximization has not precluded a growing emphasis on other corporate objectives. Many codes now include social, environmental and economic objectives as part of the fundamental objectives of an enterprise. In particular, the codes emphasize the need for enterprises to address the interests of a range of stakeholders in order to promote the long-term sustainability of the enterprise. If an enterprise knowingly damages the interests of its stakeholders, it can risk negatively affecting its own ability to produce long-term shareholder value. This suggests that, rather than viewing shareholder value and stakeholder value as mutually exclusive objectives, there are indications that the opposite is true, and that the two objectives are probably interdependent in the long run. This emphasis on a broader set of objectives can be found in the Revised OECD Guidelines on Multinational Enterprises, the 2004 edition of the OECD Principles of Corporate Governance, proposed revisions of the UK Companies Act, and the King II Report.

\section{B. Ownership and shareholder rights}

21. The ad hoc group recognized that the beneficiary ownership structure should be fully disclosed to all interested parties. It was also recognized that changes in the shareholdings of substantial investors should be disclosed to the market as soon as a company becomes aware of them. The beneficiary ownership structure of an enterprise is of great importance in an investment decision, especially with regard to the equitable treatment of shareholders. In order to make an informed decision about the company, investors need access to information regarding its ownership structure.

22. It is recommended that this disclosure include the concentration of shareholdings, for example the holdings of the top 20 largest shareholders. This information is of particular interest to minority shareholders. In some countries (e.g. Germany), disclosure is required when certain thresholds of ownership are passed.

23. The group took the view that disclosure should be made of the control structure and of how shareholders or other members of the organization can exercise their control rights through voting or other means. It also discussed the fact that any arrangement under which some shareholders may have a degree of control disproportionate to their equity ownership, whether through differential voting rights, appointment of directors or other mechanisms, should be disclosed.

24. In certain cases, control is exercised indirectly via the ownership of one or several entities that in turn (collectively) control a corporation (i.e. a pyramid structure). In such cases, the disclosure of ultimate control is considered best practice. As noted in the OECD Principles, information about record ownership may need to be complemented with information about beneficial ownership in order to identify potential conflicts of interest, related party transactions and insider trading. In disclosing beneficial (or ultimate) ownership, information should also be provided about shareholder agreements, voting caps and cross-shareholdings, as well as the rights of different classes of shares that the company may have issued.

25. A company might have a single shareholder or group of shareholders with majority control of the company, either through holding the majority of the company's outstanding equity or through holding shares with superior voting rights. In this situation, without safeguards for minority shareholders, the latter group may be adversely affected. This issue is emphasized by a number of codes, including the OECD Principles.

26. A number of international statements advocate a "one share one vote" approach. Although the OECD Principles do not advocate any particular view on the "one share one vote" approach, they include examples of other international statements that do advocate a "one share one vote" approach. The International Corporate Governance Network, among others, is a strong supporter of this approach. Advocates of the "one share one vote" approach view any deviation from this approach as an undesirable distortion of the connection between investment risk and the decision making process. However, actual practice might be different. For example, in the European Union, many member States do allow shares with multiple or no voting rights. While this practice remains controversial, it 
is tolerated by investors as long as differentials in voting rights are disclosed. The European Association of Securities Dealers does not support such differentials but allows flexibility, noting that if they cannot be avoided they should at least be indicated by a different share class (EASD Principles, Recommendation II.2).

\section{Changes in control and transactions involving significant assets}

27. The group agreed that rules and procedures governing the acquisition of corporate control in the capital markets and extraordinary transactions such as mergers and sales of substantial portions of corporate assets should be disclosed.

28. Best practice suggests a substantial amount of pre-control transaction disclosure, including the disclosure of the intention to acquire control and to take the company private and of associate squeeze-out/sell-out rights relevant for minority shareholders. Other typical disclosures include the identity of the bidder, past contacts, transactions and agreements between the merging entities (or acquirer and target, as the case may be), a discussion of the consequences of the control transaction for the shareholders of the companies involved, as well as disclosure of the financial situation of the bidder and its source of funds for the control transaction.

29. This disclosure should include any anti-takeover measures established by the enterprise. It should also cover the compensation policy for senior executives departing the firm as a result of a merger or acquisition.

30. Best practice disclosure for sales of substantial portions of corporate assets include a notice to all shareholders (usually at the annual general meeting), accompanied by an independent evaluation report. In the Republic of Korea, for example, the Corporations Code requires a special resolution for a transaction that may result in the sale of a substantial part of the enterprise. For such transactions involving listed companies, additional disclosure and substantive requirements are imposed. In South Africa, the Companies Act requires approval of the shareholder meeting for sales of the whole or the greater part of the company's assets, and for listed companies such approval is required for any transaction over 30 per cent of assets. In most governance systems, it is generally considered good practice to submit questions of extraordinary transactions (including mergers, acquisitions and takeovers) to a general meeting for shareholder approval.

31. In the interest of protecting minority shareholders, the principle of "equality of disclosure" should be practiced, such that all shareholders receive information equally. Any information disclosed to one shareholder should also be equally available to all shareholders (FEE, 2003a). This reflects the view that all shareholders should have a right to be equally informed, and complements the issue of simultaneous disclosure of information discussed in section IV below. Major shareholders such as institutional investors should not have privileged access to information that is unavailable to minority shareholders.

\section{Governance structures and policies}

\section{The structure, role and functions of the board}

32. The group recognized that the term "board" has different meanings in unitary and two-tier systems. A unitary board is comprised of executive and non-executive directors. In a two-tier system the term "board" can refer to the management board, whose members have executive responsibilities, and the supervisory board, responsible for monitoring and supervising the company's management. Variations exist among the two-tier systems, and the responsibilities of the supervisory board could in some countries include responsibilities for the strategic direction of the company. While the two-tier system is not as widely utilized as the one-tier system, it is nevertheless prevalent in several large economies such as Austria, Germany and the Netherlands. In this document, the term "board" is used to refer to the highest governing and monitoring body or bodies of an enterprise upon which executive 


\section{Page 8}

and non-executive or supervisory board members sit. The recommendations contained herein typically apply to both one-tier and two-tier systems.

33. The group took the view that the composition of the board should be disclosed, in particular the balance of executive and non-executive directors and whether any of the non-executives have any affiliations (direct or indirect) with the company. Where there might be issues that stakeholders might perceive as challenging the independence of non-executive directors, companies should disclose why those issues are not significant and do not impinge on the governance role of the nonexecutive directors.

34. One of the main issues in relation to the board structure and its disclosure is that, regardless of which structure exists in the company, independent leadership within the board is ensured. Some countries would give more emphasis to the need for a clear division of responsibilities between the chairman and the chief executive officer (CEO) (Cadbury Report, para. 4.9). Increasingly codes mention that while a combined CEO/Chair is tolerable (in a one-tier system), the separation of the two is desirable and considered best practice, as it helps to promote a balance of power within the leadership structure. There is also increasing debate on the need for an independent Chair of the board.

35. Acknowledgment of the benefits of the separation of the roles of the Chair and the CEO in a onetier system is increasing. While combining these two roles is still common, it is becoming less so. Although the general practice in some of the world's largest financial markets continues to be their combination, there are significant exceptions, such as the United Kingdom, where a combined role is increasingly rare. Even within economies where a combined role is still common, the accepted view is that measures are called for to balance the power at the head of the corporation such that no single individual has unfettered control of the company (FEE, 2003a).

36. If the roles of chairman and CEO are combined, the proportion of independent directors within the board structure assumes greater importance. For example, the Cadbury Report recommended that where the roles were combined, there should be a strong independent element on the board and that there should be a lead non-executive director to whom issues regarding the executive management could be addressed. This idea is followed by the Indian code and was also addressed in the 2002 Report of the Kumar Mangalam Birla Committee on Corporate Governance. The idea is also expressed in the Malaysian Code on Corporate Governance (2000). However, the definition of an independent director varies in different countries. Accordingly, a reference to a particular approach used in defining director independence might be useful in disclosing and discussing the board structure. FEE (2003a), for example, recommends that a principles-based approach used for assessing the independence of external auditors (see section $\mathrm{H}$ below) can also be usefully applied to the assessment of independence among non-executive (supervisory) directors. A crucial general principle in this respect is the principle on self-interest threat; a self-interest threat occurs when a director could benefit from a financial or other interest in the enterprise as a result of unethical behavior or lack of independence (FEE, 2003b). FEE further recommends that the board should disclose its reasons for considering a non-executive (or supervisory) director to be independent.

37. It is recognized that not all non-executive directors can be considered independent directors. The Narayan Murty Committee Report in India, for instance, makes a clear distinction between nonexecutive and independent directors. For example, non-executive directors who are employees of banks and other financial institutions with which the enterprise has a business relationship cannot be considered independent. Similarly, for the boards of subsidiary companies, it is not uncommon for non-executive directors to be employees of the parent firm or some other subsidiary related to the parent firm. Any relationship of directors to the parent firm or its subsidiaries should therefore be disclosed. Such a relationship could be considered in assessing the ability of the non-executive director to fulfill his or her duties. 
38. The group took the view that the board's role and functions must be fully disclosed. Most guidelines and codes of best practice emphasize the stewardship and supervision functions of the board and distinguish its responsibilities from those of management. It is important that directors disclose what their functions and retained powers are, otherwise the directors may be considered accountable for all matters connected to the enterprise. In many Commonwealth countries, for example, the Companies Act makes the directors accountable for the 'management' of the company, but also allows the directors to delegate; hence the importance of recording and disclosing the retained powers of the directors, along with a clear statement about which powers are delegated to the CEO. However, there are differences in the specificity with which the board's role is explained. For example, the Dey Report (Canada), the Vienot Report (France), the Korean Stock Exchange Code, Malaysia's Report on Corporate Governance, Mexico's Code of Corporate Governance, and the King II Report (South Africa) specify board functions as strategic planning, risk identification and management selection, oversight and compensation of senior management, succession planning, communications with shareholders, integrity of financial controls and general legal compliance. In India, for example, a directors' responsibility statement outlining the board's responsibilities on compliance with standards, internal controls, risk management, fraud detection and other matters is a disclosure requirement under both the law and stock exchange rules. The degree of differences between codes may reflect the degree to which company law or listing standards specify board responsibilities.

\section{Board committees}

39. It has become common practice for boards to establish board committees to facilitate fulfillment of certain of the board's functions and address some potential conflicts of interest. The use of board committees is, among other things, intended to enhance independent judgment on matters in which there is potential for conflict of interest, and to bring special expertise in areas such as audit, risk management, election of board members and executive remuneration. While it may be advisable for the preparatory work of certain key board functions to be assigned to separate committees, there is an international consensus that the full board holds collective and final responsibility (FEE, 2003a). A number of codes address this issue, also outlining the need for clear terms of reference for such committees (e.g. Australia, India, Malaysia, South Africa).

40. The ad hoc consultative group suggested that governance structures should be disclosed. In particular, the group agreed that the board should disclose structures put in place to prevent conflicts between the interests of the directors and management on the one side, and those of shareholders and other stakeholders on the other. These structures may include committees or groups to which the board has assigned duties regarding the oversight of executive remuneration, audit matters, appointments to the board, and the evaluation of management performance.

41. It was also agreed that the composition and functions of any such groups or committees should be fully disclosed. Committee charters, terms of reference, or other company documents outlining the duties and powers of the committee or its members should also be disclosed, including whether or not the committee is empowered to make decisions which bind the board, or whether the committee can only make recommendations to the board. If any director has taken on a specific role for the board or within one of these structures, this should be disclosed.

42. As a general rule, codes have recommended, and in some cases stock exchange regulations require, that some board committees be substantially or exclusively staffed by non-executive or outside directors, particularly independent directors, and especially with regard to the committee chairpersons. Disclosures that are becoming increasingly common include the disclosure of committee charters or terms of reference, committee chairs, reports on activities (in particular those of the audit committee), composition, nominations committee disclosure on whether use is made of external advisors/advertising to find new directors (as opposed to potentially conflicting informal connections), and the effectiveness of executive remuneration in providing incentives for executives. 


\section{Ethics policy and support structure}

43. The existence of an enterprise code of ethics and any governance structure put in place to support that code of ethics should be disclosed. Any waivers to the code of ethics or the rules governing ethics procedures should also be disclosed.

44. Ethics management is important to the promotion of good business practices, transparency and risk reduction. As ethics management becomes more common in enterprises, the existence of its key structural features is an important area of disclosure. It is noted that, with the exception of some countries such as the United States, no general or international best practice has yet been established in this area. Nevertheless, some possible features subject to disclosure might include: the existence of a senior ethics officer and that person's responsibilities; the existence of an ethics committee and its relationship to the board; policies for breaches of the ethics code, including reporting mechanisms and 'whistleblower' protection mechanisms; and policies on the dissemination and promotion of the ethics code.

\section{E. Members of the board and key executives}

\section{Duties and qualifications}

45. The group recommended that the number, type and duties of board positions held by an individual director should be disclosed. An enterprise should also disclose the actual board positions held, and whether or not the enterprise has a policy limiting the number of board positions that any one director can hold.

46. The group discussed the issue of shareholders needing to be aware of the number, type and duties of outside board and management positions that any individual director holds. Information for outside board and management positions should be disclosed for key executives as well. The purpose of this information is to make a judgment on the ability of directors and key executives to meet all of their commitments; thus the number as well as the type and duties of the position (which gives some indication of the commitment involved) are the subject of disclosure.

47. Many codes and institutional investors have specified disclosure requirements (and/or actual limitations) on the number and type of positions held by directors. Among others, such disclosure requirements, can be found in the positions of the FEE and the Winter Group Report, the Dey Report, the Indian Code, the Malaysian Code, the King II Report, the National Association of Pension Funds in the United Kingdom. Some guidance, such as the report of FEE, also recommends disclosure of positions held in public or not-for-profit organizations.

48. The experts took the view that there should be sufficient disclosure of the qualifications and biographical information of all board members to assure shareholders and other stakeholders that the members can effectively fulfill their responsibilities. There should also be disclosure of the mechanisms which are in place to act as "checks and balances" on key individuals in the enterprise.

49. Most governance guidelines and codes of best practice address topics related to directors' qualifications and board membership criteria. These may include experience, personal characteristics, core competencies, availability, diversity, age, specific skills (e.g. the understanding of particular technologies), international background, and so on. The CACG, for example, advocates that the director has to have integrity, common sense, business acumen and leadership. Some codes specifically require financial literacy (e.g. the National Association of Corporate Directors in the United States) or knowledge of business and financial technology (e.g. the Brazilian Institute of Corporate Governance). 
50. There should be disclosure of the types of development and training that directors undergo at induction, as well as the actual training directors received during the reporting period.

51. Recently, some countries have started to require specific training for directors. For example, in India, the Companies (Amendment) Bill 2003 makes director training mandatory. The Naresh Chandra Committee on Corporate Audit and Governance, also of India, recommends training for independent directors and disclosure thereof.

52. The group suggested that the board should disclose facilities which may exist to provide members with professional advice. The board should also disclose whether that facility has been used during the reporting period.

53. The group realized that, on certain legal and financia 1 matters, directors might discharge their duties more effectively if allowed access to independent external advisors, for example legal and financial experts. If used correctly, access to external expertise can enhance the ability of directors to fulfill their duties properly. In New Zealand, for example, it is considered vital for directors to have access to independent advice, and therefore this principle is stated in that country's Companies Act. The Merged Code in Belgium also points out the need for an agreed procedure for using external expertise, a point also mentioned in the Dey Report (Canada), Vienot (France), Mertanzis (Greece) and Olivencia (Spain) reports. Best practice suggests that, whatever approach is used, the approach should be disclosed.

\section{Evaluation mechanism}

54. The ad hoc group agreed that the board should disclose whether it has a performance evaluation process in place, either for the board as a whole or for individual members. Disclosure should be made of how the board has evaluated its performance and how the results of the appraisal are being used. Along with the duties and responsibilities of directors, shareholders will need to know how directors were evaluated, what criteria were used and how they were applied in practice, particularly with reference to remuneration.

55. CACG Guidelines stress that evaluations should be based on objective criteria. The IAIM Guidelines (Ireland) and Preda Code (Italy) leave to the remuneration committee the selection of appropriate criteria and the establishment of whether these criteria have been met.

56. An important aspect of performance is the attendance of directors at board and committee meetings. Specific requirements regarding the frequency and procedures of board meetings can be found, for example, in the Indian Code, the King II Report and the Combined Code of United Kingdom.

\section{Directors' remuneration}

57. The ad hoc consultative group took the view that directors should disclose the mechanism for setting directors' remuneration and its structure. A clear distinction should be made between remuneration mechanisms for executive directors and non-executive directors. Disclosure should be comprehensive to demonstrate to shareholders and other stakeholders whether remuneration is tied to the company's long-term performance as measured by recognized criteria. Information regarding compensation packages should include salary, bonuses, pensions, share payments and all other benefits, financial or otherwise, as well as reimbursed expenses. Where share options for directors are used as incentives but are not disclosed as disaggregated expenses in the accounts, their cost should be fully disclosed using a widely accepted pricing model.

58. The current level of disclosure relating to directors' remuneration varies widely. However the trend appears to be towards greater levels of disclosure in this area, especially in Europe: France, Germany, Luxembourg, the Netherlands, Switzerland and the United Kingdom have all introduced 


\section{Page 12}

laws to enforce the disclosure of directors' individual remuneration. In the United Kingdom, for example, the report of the company's remuneration committee must identify each director and specify his or her total compensation package, including share options. Recently added regulations also require companies to put their remuneration report to a shareholder vote at each annual general meeting. Other examples of this practice exist elsewhere in the world. The Indian Code, for instance, requires disclosure about remuneration in a section of the annual report on corporate governance, in addition to suitable disclosure on director's remuneration in the profit and loss statement.

59. The group discussed the fact that the length of directors' contracts, the termination of service notice requirements, as well as the nature of compensation payable to any director for cancellation of a service contract should be disclosed. Specific reference should be made to any special arrangement relating to severance payments to directors in the event of a takeover.

\section{Succession planning}

60. The group took the view that the board should disclose whether it has established a succession plan for key executives and other board members to ensure that there is a strategy for continuity of operations.

61. OECD Principle IV.D.2 stresses that overseeing succession planning is a key function of the board, while the Dey Report (Canada) considers it an important stewardship duty of the company, and the Vienot Report I (France) recommends that the selection committee be prepared to propose successors at short notice. While specific details regarding potential successors might be the subject of confidentiality, the existence of a procedure and a preparedness to appoint successors as necessary is not confidential, and should be the subject of disclosure.

\section{Conflict of interest}

62. The group suggested that conflicts of interests affecting members of the board should, if they are not avoidable, at least be disclosed. The board of directors should disclose whether it has a formal procedure for addressing such situations, as well as the hierarchy of obligations to which directors are subject.

63. Conflicts of interest are required to be disclosed by law in many countries. The critical issue is that all conflicts of interest should be disclosed, along with what the board decided to do regarding the specific situation and the relevant director involved.

\section{F. Material issues regarding stakeholders, environmental and social stewardship}

64. The group recommended that the board should disclose whether there is a mechanism protecting the rights of other stakeholders in a business.

65. OECD Principle IV concerns itself with ensuring that the rights of stakeholders protected by law are respected. Even where no legislation exists, it is considered good practice to make additional commitments, as corporate reputation and performance may require recognition of broader interests. For example, the CACG Guidelines require that a board identify the corporation's internal and external stakeholders and agree on a policy for how the corporation should relate to them.

66. The role of employees in corporate governance should be disclosed. Among member States of the European Union, for example, various practices exist where employees elect some of the supervisory directors, can be given a right to nominate one or more directors or can have an advisory voice on certain issues discussed by the board. This practice is considered by some to dilute the influence of shareholders, and to be a distortion of the connection between investment risk and the decision-making process. Others consider the strong interest of employees in the enterprise to warrant their special status in the governance process, and view employee involvement as having a beneficial 
effect on the overall sustainability of the firm. Regardless of one's views, any mechanisms for employee involvement in the governance of the enterprise should be clearly disclosed.

67. The group took the view that the board should disclose its policy and performance in connection with environmental and social responsibility and the impact of this policy and performance on the firm's sustainability. The environmental dimension of this issue was addressed by ISAR in its agreed conclusions on Accounting and Financial Reporting for Environmental Costs and Liabilities. ISAR noted that an enterprise's environmental performance could affect its financial health and hence its sustainability. At its twentieth session, ISAR concluded that the pressure for better reporting on social issues was increasing and that enterprises were producing more information on this topic. Among others, the King II Report (South Africa), the Association of British Insurers (UK) in its Disclosure Guidelines on Socially Responsible Investment, and the guidelines of the Global Reporting Initiative encourage disclosure of governance mechanisms in place to support improvement of social and environmental performance. Such governance disclosure is also relevant for creators of 'socially responsible investing' indexes, such as the Domini 400 Social Index produced by KLD Research \& Analystics in the United States, the FTSE4GOOD produced by FTSE in the United Kingdom, or the Dow Jones Sustainability World Indexes (DJSI) produced by the SAM Group of Switzerland in conjunction with Dow Jones Ltd and STOXXX Ltd.

\section{G. Material foreseeable risk factors}

68. The group took the view that the board should give appropriate disclosures and assurance regarding its risk management objectives, systems and activities. In particular, it was agreed that the board should disclose existing provisions for identifying and managing the effects of risk-bearing activities. The board should report on internal control systems designed to mitigate risks. Such reporting should include risk identification mechanisms.

69. In recent years, much attention has been paid to the role of the board in risk assessment or management and internal controls designed to mitigate risk. This issue is emphasized in most codes and principles, including the OECD Principles, the CACG Guidelines, King II, and the United Kingdom's Combined Code.

70. Users of financial information and participants in the marketplace need information on foreseeable material risks, including risks specific to industries or geographical areas, dependence on certain commodities, financial market risk and derivative risks. The corporate governance structures in place to assess, manage and report on these types of risks should be the subject of corporate governance disclosure.

\section{H. Independence of external auditors}

71. The group agreed that the board should disclose that it has confidence that the external auditors are independent and their competency and integrity have not been compromised in any way. The process for the appointment of and interaction with external auditors should be disclosed.

72. Independent external audits should provide an objective assurance that the financial statements present a true and fair view (or are presented fairly in all material respects) of the financial condition and performance of the audited entity. Accordingly, most governance codes and guidelines define procedures for enhancing the independence, objectivity and professionalism of the external audit. A number of approaches regarding the external audit, such as the need for auditor partner rotation and the avoidance of possible conflicts of interest involved in providing non-audit services, can be considered to ensure that external audits serve shareholder and other stakeholder interests in the intended manner.

73. Auditors' independence is a prerequisite for the reliability and credibility of the audit of financial statements. A principles-based approach to auditor independence (as set out in the EC's 2002 


\section{Page 14}

recommendation on auditor independence and in the IFAC Code of Ethics) is valued for its adaptability to new practices. The principles-based approach sets out the fundamental principles that must always be observed by the auditor and considers the threats and safeguards (including restrictions and prohibitions) to be in place to ensure the auditor's independence and objectivity. However, it could be useful for enterprises to disclose a substantial definition of those activities that would be regarded as non-audit-related, especially in those cases where audit and non-audit-related fees are not subject to mandatory disclosure.

74. Disclosures should cover the selection and approval process for the external auditor, any prescriptive requirements for audit partner rotation, the duration of the current auditor (e.g. whether the same auditor has been engaged for more than five years and whether there is a rotation of audit partners), who governs the relationship with the auditor, whether auditors do any non-audit work and what percentage of the total fees paid to the auditor involves non-audit work.

75. The audit committee should play a role in establishing a policy on purchasing non-audit services from the external auditor; this policy should be disclosed along with an explanation or assessment of how this policy sufficiently ensures the independence of the external auditor (FEE, 2003a).

\section{Internal audit function}

76. Enterprises should disclose the scope of work and responsibilities of the internal audit function, as well as the highest level within the leadership of the enterprise to which the internal audit function reports. Enterprises with no internal audit function should disclose the reasons for its absence.

77. The group recognized that an effective internal audit function plays a significant role within the corporate governance framework of a company. The scope of work and responsibilities of an internal audit function are often determined by the board (or management board in a two-tier system), typically in conjunction with the audit committee, and can vary significantly depending on the size, structure and complexity of the company and the resources allocated. Given the potential variation in the internal audit function among enterprises, it is recommended that relevant details of this function be disclosed.

\section{GENERAL MEETINGS}

78. The group discussed the fact that disclosure should be made of the process for holding and voting at annual general meetings and extraordinary general meetings, as well as all other information necessary for shareholders to participate effectively in such meetings. Notification of the agenda and proposed resolutions should be made in a timely fashion, and be made available in the national language (or one of the official languages) of the enterprise as well as, if appropriate, an internationally used business language. The results of a general meeting should be communicated to all shareholders as soon as possible.

79. The OECD Principles outline a general consensus as to the nature of shareholder meetings and the requirement to make shareholder participation as simple and effective as possible and ensure the equitable treatment of all shareholders. The Principles state that shareholders should be informed of the rules and be furnished with information regarding the date, location and agenda of the meeting, as well as the issues to be decided. Sufficient information should be provided so that shareholders can make fully informed decisions. Enterprises should do everything possible to facilitate the effective participation of all (including foreign) shareholders in general meetings.

80. In most governance systems, it is either required or considered good practice to put certain issues to shareholder approval at a general meeting. Best practice in this area entails that issues subject to shareholder approval be presented individually and unbundled, allowing shareholders to accurately 
exercise their voting rights. These rules can vary across different countries, and therefore disclosing information on the subject would be useful, especially for foreign investors.

81. The experts noted that in some countries, for some enterprises, new types of voting technology are being employed, for example Internet voting. The enterprise should, when issuing notice of the meeting, disclose the relevant details of voting technologies employed.

82. The enterprise should disclose all relevant information on the process by which shareholders can submit agenda items, and should disclose which shareholder proposals (if any) were excluded from the agenda and why. It is considered good practice in most governance systems to allow shareholders to include items on the agenda of a general meeting.

\section{TIMING AND MEANS OF DISCLOSURE}

83. The group agreed that all material issues relating to corporate governance of the enterprise should be disclosed in a timely fashion. The disclosure should be clear, concise, precise and governed by the "substance over form" principle. Some issues may require continuous disclosure. Relevant information should be available for users in a cost-effective way, preferably through the websites of the relevant government authority, the stock exchange on which the enterprise is listed (if applicable), and the enterprise itself.

84. The location of corporate governance disclosures within the annual report is not generally defined and can vary substantially in practice. Some degree of harmonization of the location of corporate governance disclosures would be desirable to make the relevant data more accessible. Two possible approaches include putting all corporate governance disclosures in a separate section of the annual report, or putting them in a stand-alone corporate governance report. Examples of the former approach are found in the recommendations of the Hong Kong Society of Accountants and the listing requirements in India and Switzerland, which provide for corporate governance disclosures to appear in a separate section of the annual report and in a prescribed format. Where corporate governance disclosures are not consolidated, there should be sufficient cross referencing to different disclosures to improve accessibility to the information.

85. Some information related to corporate governance may require immediate disclosure, and some codes and listing requirements address this issue. For example, in Malaysia listing requirements call for immediate disclosure of a change in the management, external auditor or board structure.

86. It is widely recognized that traditional channels of communication with stakeholders, such as annual reports, should be supported by other channels of communication taking into account the complexity and globalization of financial markets and the impact of technology. The OECD Principles state that the Internet and other information technologies provide the opportunity for improving information dissemination. In some countries (e.g. the United States), Internet disclosure is now accepted as legal disclosure and annual reports must indicate where company information can be found on the Internet. The King II Report also emphasizes the need for critical financial information to be made available to shareholders simultaneously and supports the idea that traditional channels of communication be complemented by new means, such as the Internet.

87. Whatever disclosures are made and whatever channels used, a clear distinction should be made between audited and un-audited financial information, and means of validation of other non-financial information should be provided.

\section{GOOD PRACTICES FOR COMPLIANCE}

88. The ad hoc consultative group recognized that, where there is a local code on corporate governance, enterprises should follow a "comply or explain" rule wherein they disclose the extent 
Page 16

to which they followed the local code's recommendations and explain any deviations. Where there is no local code on corporate governance, companies should follow recognized international good practices.

89. The use of "comply or explain" mechanisms in many countries allows investors and other stakeholders greater access to information about the corporation and is to be encouraged. Related to this "comply or explain" rule, some countries now require companies with foreign listings to disclose the extent to which the local governance practices differ from the foreign listing standards.

90. The enterprise should disclose awards or accolades for its good corporate governance practices. It is recognized that there is an increase in the number of corporate governance accolades, awards, ratings, rankings and even corporate governance stock market indexes where constituents are selected on the basis of good practices in corporate governance. Especially where such awards or recognitions come from major rating agencies, stock exchanges, or other significant financial institutions, disclosure would prove useful, since it provides independent evidence of the state of a company's corporate governance.

\section{CONCLUSIONS}

91. This report has considered a range of areas in which disclosure may be advantageous to users of corporate information. It has discussed disclosure relating to various categories of financial and nonfinancial information. It has examined disclosure related to general meetings, the timing and means of disclosure, and disclosure on the adoption of best practices in compliance with corporate governance requirements.

92. In looking at areas where disclosure is necessary, the report has given examples from best practice codes from a number of countries. Although the review of such regional and national codes is by no means exhaustive, an attempt has been made to present a balanced review.

93. In accordance with the agreement reached at the twenty-first session of the Group of Experts, the UNCTAD secretariat is presenting this updated version of the 2002 report for consideration by the twenty-second session of ISAR. If the twenty-second session finds these revisions comprehensive and acceptable, it could recommend the finalization and dissemination of this report as voluntary guidance on good practices on corporate governance disclosure that could contribute towards further convergence of disclosures in this area to improve corporate transparency and facilitate investment. 


\section{Annex I}

\section{REFERENCES}

\section{International organizations}

CACG (2003). Corporate Governance Principles for Annual Reporting in the Commonwealth. Commonwealth Association of Corporate Governance.

EASD (2000). Corporate Governance: Principles and Recommendations. European Association of Securities Dealers.

EC (2002a). Comparative Study of Corporate Governance Codes to the European Union and Member States. European Commission, Internal Market Directorate General.

EC (2002b). Report of the High Level Group of Company Law Experts on a Modern Regulatory Framework for Company Law in Europe, (a.k.a. "The Winter Group Report"). European Commission. November.

EC (2002c). Recommendation on statutory auditors' independence in the EU. European Commission. May.

EC (2004). Directive on minimum transparency requirements for listed companies. European Commission. December.

Euroshareholders (2000). Euroshareholders Corporate Governance Guidelines.

FEE (2003a). Discussion Paper on the Financial Reporting and Auditing Aspects of Corporate Governance. European Federation of Accountants.

FEE (2003b). Conceptual Approach to Safeguarding Integrity, Objectivity and Independence Throughout the Financial Reporting Chain. European Federation of Accountants.

FEE (2004). Study on Mandatory Rotation of Audit Firms. European Federation of Accountants.

FEE (2005). Discussion Paper on Risk Management and Internal Control in the EU. European Federation of Accountants.

GRI (2002) Sustainability Reporting Guidelines. Global Reporting Initiative.

ICGN (1999). Statement on Global Corporate Governance Principles. International Corporate Governance Network.

ICGN (2005). Revised Statement on Global Corporate Governance Principles. International Corporate Governance Network.

IASB (2005). Framework for the Preparation and Presentation of Financial Statements. International Accounting Standards Board.

IOSCO (2002). Principles of Auditor Independence and the Role of Corporate Governance in Monitoring an Auditor's Independence. International Organisation of Securities Commissions.

ISAR (1989). Conclusions on Disclosure Requirements Concerning the Annual Report of the Board of Directors (E/C.10/AC.3/1989/6). Intergovernmental Working Group of Experts on International Standards of Accounting and Reporting. 
Page 18

OECD (1999). Principles of Corporate Governance. Organisation for Economic Cooperation and Development.

OECD (2000). Revised Guidelines for Multinational Enterprises. Organisation for Economic Cooperation and Development.

OECD (2004). Principles of Corporate Governance (2004 Edition). Organisation for Economic Cooperation and Development.

UNCTAD (1999). Accounting and Financial Reporting for Environmental Costs and Liabilities (UNCTAD/ITE/EDS/4). United Nations Conference on Trade and Development.

UNCTAD (2000). Integrating Environmental and Financial Performance at the Enterprise Level (UNCTAD/ITE/TED/1). United Nations Conference on Trade and Development.

World Bank (2000). Corporate Governance ROSC for Malaysia .

World Bank (2002). The State of Corporate Governance: experience from country assessments, Mierta Capaul and Olivier Fremond, Policy Research Working Paper.

World Bank (2003a). Corporate Governance ROSC for Hong Kong.

World Bank (2003b). Corporate Governance ROSC for Korea.

World Bank (2003c). Corporate Governance ROSC for Mexico.

World Bank (2003d). Corporate Governance ROSC for South Africa.

World Bank (2003e). Accounting and Auditing ROSC for South Africa.

World Bank (2004a). Implementation of International Accounting and Auditing Standards: Lessons Learned from the World Bank's Accounting and Auditing ROSC Program. Hegarty, Gielen, Hirata Barros, World Bank.

World Bank (2004b). Corporate Governance ROSC for India.

World Bank (2004c). Accounting and Auditing ROSC for India.

World Bank (2004d). Accounting and Auditing ROSC for Mexico.

\section{Australia}

Working Group representing the Australian Institute of Company Directors, the Australian Society of Certified Practicing Accountants, the Business Council of Australia Law Council of Australia, the Institute of Chartered Accountants in Australia and the Securities Institute of Australia (1995). Bosch Report: Corporate Practices and Conduct.

\section{Belgium}

Brussels Stock Exchange (1998). Report of the Belgium Commission on Corporate Governance (Cardon Report).

Brussels Stock Exchange Banking and Finance Commission (1998). Corporate Governance for Belgian Listed Companies (Merged Code). 
Corporate Governance Committee (2004). The Belgian Code on Corporate Governance ('Lippens Code')

\section{Brazil}

Instituto Brasileiro de Governança Corporativa (Brazilian Institute of Corporate Governance) (2001). Code of Best Practice of Corporate Governance.

\section{Canada}

Toronto Stock Exchange Committee on Corporate Governance in Canada (1994). Where Were the Directors? Guidelines for Improved Corporate Governance in Canada (Dey Report).

\section{France}

Association Française des Entreprises Privées, Association des Grandes Entreprises Françaises, and Mouvement des Entreprises de France (2002). Promoting Better Corporate Governance in Listed Companies (Daniel Bouton Committee).

Association Française des Entreprises Privées and Mouvement des Entreprises de France (1999). Report on the Committee on Corporate Governance (Vienot II).

Association Française de la Gestion Financière - Association des Sociétés et Fonds Français d'Investissement (1998). Recommendations on Corporate Governance (Hellebuyck Commission Recommendations).

Conseil National du Patronat Français and Association Française des Entreprises Privées (1995). The Board of Directors of Listed Companies in France, (Vienot I).

\section{Germany}

Berliner Initiativkreis (Berlin Initiative Group) (2000). German Code for Corporate Governance.

Government Commission on the German Corporate Governance Code (2005). The German Corporate Governance Code ('Cromme Code')

Grundsatzkommission Corporate Governance (German Panel for Corporate Governance) (2000). Corporate Governance Rules for German Quoted Companies.

\section{Greece}

Capital Market Commission's Committee on Corporate Governance in Greece (1999). Principles on Corporate Governance in Greece: Recommendations for Its Competitive Transformation (Mertzanis Report).

\section{Hong Kong, China}

The Stock Exchange of Hong Kong (2000). Code of Best Practice.

Hong Kong Society of Accountants (2001) Corporate Governance Disclosure in Annual Reports: A Guide to Current Requirements and Recommendations for Enhancement.

\section{India}

Confederation of Indian Industry (1998). Desirable Corporate Governance - A Code.

Committee Appointed by the SEBI on Corporate Governance under Chairmanship of Shri Kumar Mangalam Birla (2002) Report of the Kumar Mangalam Birla Committee on Corporate Governance. 
Page 20

\section{Ireland}

Irish Association of Investment Managers (1999). Corporate Governance, Share Options and Other Incentive Scheme Guidelines.

\section{Italy}

Comitato per la Corporate Governance delle Società Quotate (Committee for the Corporate Governance of Listed Companies) (1999). Report and Code of Conduct (Preda Report).

Ministry of the Italian Treasury (1997). Report of the Draghi Committee.

\section{Korea (Republic of)}

Committee on Corporate Governance (1999). Code of Best Practice for Corporate Governance.

\section{Kyrgyzstan}

Prime Minister's Office of the Kyrgyz Republic (1997). Department of Economic Sectors Development, Model Charter of a Shareholding Society of Open Type.

\section{Malaysia}

JPK Working Group I on Corporate Governance in Malaysia (2000). Report on Corporate Governance in Malaysia.

Finance Committee on Corporate Governance (2000). Malaysian Code on Corporate Governance.

Kuala Lumpur Stock Exchange Listing Requirements as of January 2005.

\section{Mexico}

Consejo Coordinador Empresarial and La Comisión Nacional Bancaria y de Valores (1999). Código de Mejores Práticas.

\section{Netherlands}

Committee on Corporate Governance (1997). Corporate Governance in the Netherlands - Forty Recommendations (Peters Code).

\section{South Africa}

Institute of Directors in Southern Africa (1994). The King I Report on Corporate Governance.

Institute of Directors in Southern Africa (2002). The King II Report on Corporate Governance.

\section{Spain}

Comisión Especial para el Estudio de un Código Etico de los Consejos de Administración de las Sociedades (1998). El Gobierno de las Sociedades Cotizadas (Olivencia Report).

\section{Switzerland}

SWX Swiss Exchange (2002). Directive on Information Relating to Corporate Governance.

\section{Thailand}

The Stock Exchange of Thailand (1998). The Roles, Duties and Responsibilities of the Directors of Listed Companies. 


\section{United Kingdom}

Association of British Insurers (2001). Disclosure Guidelines on Socially Responsible Investment.

Cadbury Commission (1992). Report of the Committee on the Financial Aspects of Corporate Governance (Cadbury Report).

Department of Trade and Industry (2003). The Operating and Financial Review Working Group on Materiality.

Institute of Chartered Accountants in England and Wales (1999). Internal Control: Guidance for Directors on the Combined Code (Turnbull Report).

Institute of Chartered Secretaries and Administrators (1996) Electronic Communications with Shareholders

London Stock Exchange Committee on Corporate Governance (1998). The Combined Code: Principles of Good Governance and Code of Best Practice.

National Association of Pension Funds (1999). Corporate Governance Pocket Manual.

\section{United States}

Conference Board (2003). Findings and Recommendations. The Conference Board Commission on Public Trust and Private Enterprise.

General Motors Board of Directors (2000). GM Board of Directors Corporate Governance Guidelines on Significant Corporate Governance Issues.

National Association of Corporate Directors (2000). Report of the NACD Blue Ribbon Commission on Performance Evaluation of Chief Executive Officers, Board and Directors.

NACD (1999). Report and Recommendations of the Blue Ribbon Committee on Improving the Effectiveness of Corporate Audit Committees.

Sarbanes-Oxley Act (2002)

\section{Other Literature}

Berle AA and Means GD (1932). The Modern Corporation and Private Property. New York, Macmillan.

Frederick, R (2004). "The Role of the Board in Disclosure: An Examination of What Codification Efforts Say". Paper prepared for the South-Eastern Europe Corporate Governance Roundtable on Transparency and Disclosure: Implementation and Enforcement, sponsored by the OECD.

Gomez S (2002). Examples of corporate governance in Spain. Working paper, University of Oviedo, Spain.

Gordon, JN (2005). "Executive Compensation: If There's a Problem, What's the Remedy? The Case for 'Compensation Disclosure and Analysis"', Columbia Law School and European Corporate Governance Institute (ECGI).

Gregory, HJ and Weil, Gotshal \& Manges LLP (2000). "International Comparison of Corporate Governance Guidelines and Codes of Best Practices: Investor Viewpoints" 
TD/B/COM.2/ISAR/30

Page 22

Gregory, HJ and Weil, Gotshal \& Manges LLP (2001a). "International Comparison of Corporate Governance Guidelines and Codes of Best Practices: Developed Markets"

Gregory, HJ and Weil, Gotshal \& Manges LLP (2001b). "International Comparison of Corporate Governance Guidelines and Codes of Best Practices: Developing and Emerging Markets"

IRRC (1999). Global Corporate Governance Codes. Investor Responsibility Research Center, Washington, D.C.

Jolles, IH (2003). "Sarbanes-Oxley: The New Audit Committee and The Exercise of Due Care", Securities and Commodities Regulation, June 11.

KPMG (2002). Corporate Governance in Europe, KPMG Survey.

Melis A (2002). Examples of corporate governance in Italy. Working paper, University of Cagliari, Italy.

Monks RAG and Minow N (1991). Power and Accountability. New York, HarperCollins.

Weil, Gotshal \& Manges LLP (2002). "Comparative Study of Corporate Governance Codes Relevant to the European Union and its Member States".

\section{Internet}

European Corporate Governance Institute. (In particular, see index of corporate governance codes by country.) www.ecgi.org 


\section{Annex II}

\section{MEMBERS OF THE AD HOC CONSULTATIVE GROUP*}

Ms. Carlotta Amaduzzi - Institutional Shareholder Services (United States)

Mr. André Baladi - Co-Founder, International Corporate Governance Network

Mr. Ian Ball - International Federation of Accountants

Mr. John Barrass - CFA Institute

Mr. Igor Belikov - Russian Institute of Directors

Mr. Robert Blanks - Institute of Chartered Secretaries and Administrators (United Kingdom)

Mr. Geoffrey Bowes - The Boardroom Practice Ltd. (New Zealand)

Ms. Jacqueline Cook - The Corporate Library (United States)

Mr. David Devlin - European Federation of Accountants

Mr. Richard Frederick - Consultant

Mr. Ndung'u Gathinji - International Federation of Accountants

Mr. Frederic Gielen - World Bank Group

Mr. Winston Griffin - Proctor \& Gamble (Switzerland)

Mr. Ashok Haldia - Institute of Chartered Accountants of India

Mr. Paul Lee - Hermes Investment Management Ltd. (United Kingdom)

Mr. Paul Moxey - Association of Chartered Certified Accountants (United Kingdom)

Mr. Matthias Mueller - International Confederation of Free Trade Unions

Mr. Vijay Poonoosamy - Commonwealth Association of Corporate Governance

Mr. Gregor Pozniak - Federation of European Securities Exchanges

Mr. Paolo Santella - CEC European Commission

Ms. Saskia Slomp - European Federation of Accountants

\footnotetext{
* The views contained in this document do not necessarily reflect those of the organizations with which the members of the ad hoc consultative group are affiliated.
} 